\title{
A comparison of science classroom environments between Korea and Thailand with a focus on their cultural features
}

Jina Chang ${ }^{4}$, Chatree Faikhamta ${ }^{2}$, Jiyeon $\mathrm{Na}^{3}$ and Jinwoong Song ${ }^{1 *}$

\author{
* Correspondence: \\ jwsong@snu.ac.kr \\ 'Department of Science Education, \\ College of Education, Seoul \\ National University, Seoul, Republic \\ of Korea \\ Full list of author information is \\ available at the end of the article
}

\begin{abstract}
Every classroom environment reflects the cultural features of the country where it is located. In this study, with a focus on cultural features, we compared the science classroom environments of two Asian countries: Korea and Thailand. For this, What is Happening In this Class (WIHIC) and the Cultural Learning Environment Questionnaire (CLEQ) were administered to 1575 students (765 from Korea and 810 from Thailand) in Grades 4, 6, 8, and 10. The results of two instruments were analyzed and discussed with a particular focus on the four cultural dimensions in science classrooms, which were reframed from Hofstede's four cultural dimensions. The results of the analysis can be summarized as follows. First, regarding the first dimension, relationships between individuals and groups, students in both countries liked collaborative activities and had many emotional exchanges in their classrooms. However, cognitive collaborative activities occurred more frequently in Thailand than in Korea. Second, regarding the second dimension, equity issues, almost all students in Korea perceived that they participated equally in science classrooms. However, in Thailand, students thought they had equal participation in science classrooms except for the gender aspects. That is, Thai boys and girls were reported themselves to be participating in different ways in their classrooms. Third, regarding the third dimension, relationships between students and teachers, two kinds of relationships were investigated: teacher authority and teacher support. In terms of teacher authority, the extent of psychological distance between students' and their teachers' power was similar in the two countries. However, in terms of teacher support, Thai students had more positive perceptions about teacher support than Korean students did. Fourth, regarding the features of science teaching and learning processes, Korean students had more negative perceptions of involvement, investigation, and task orientation than Thai students did. The negative responses of Korean students could be the cause of the low engagement of Korean students in their science classrooms. Based on these results, educational implications are discussed in terms of culturally appropriate pedagogies in science classrooms.
\end{abstract}

Keywords: Science classroom environment, Korea, Thailand, Cultural feature 
초록

모든 교실 환경은 각 나라의 문화적 특징을 반영한다. 본 연구는 문화적 관점에 서 두 개의 아시아 국가인 한국과 태국의 과학교실 환경을 비교하였다. 이를 위 해, What Is Happening In this Class (WIHIC)과 the Cultural Learning Environment Questionnaire $(\mathrm{CLEQ})$ 를 활용하여 초등학교 4학년과 6학년, 중학교 2학년, 고등 학교 1학년 1575명의 학생들(한국 765명, 태국 810명)의 과학교실에 대한 인식 을 조사하였다. 특히 Hofstede의 4가지 문화적 차원을 토대로 재구성된 '과학교 실에서의 4가지 문화적 특징'에 초점을 맞추어 설문 결과를 분석하고 논의하였 으며, 연구 결과는 다음과 같다. 첫째, 개인과 집단과의 관계 측면에서 양국의 학생들은 협동적인 활동을 좋아하였고 과학교실에서 감정적인 교류가 많았다. 그러나 인지적 협업 활동은 한국에서보다 태국에서 더 많이 일어나는 것으로 보고되었다. 둘째, 교실에서의 형평성 문제와 관련하여, 한국 학생들 대부분은 과학교실에서 공평하게 참여한다고 응답했다. 태국 학생들도 대체로 공평하게 참여한다고 인식했으나, 양성 평등 측면에서는 그렇지 못했다. 다시 말해, 태 국 남학생과 여학생들은 교실에서 서로 다른 방식으로 참여하고 있다고 생각 했다. 셋째, 학생과 교사와의 관계와 관련해서는 교사 권위 및 교사 지원에 대 한 두 가지 측면의 관계를 보고하였다. 교사 권위의 측면에서, 양국의 학생들이 느끼는 교사와의 권력 거리는 비슷했다. 하지만, 교사 지원의 측면에서 태국 학 생들이 한국 학생들보다 교사로부터 긍정적인 지원을 받는다고 인식했다. 넷 째, 과학 교수학습 과정에서의 특징과 관련하여, 한국 학생들이 태국 학생들보 다 참여, 탐구, 과제 지향 측면에서 부정적인 인식을 가지고 있었다. 한국 학생 들의 부정적인 인식은 과학교실에서의 낮은 참여의 원인이 될 수 있다. 이러한 결과들을 토대로, 문화적 특징을 고려한 과학교실에서의 교수학습 방법에 대 한 교육적 시사점을 논의하였다.

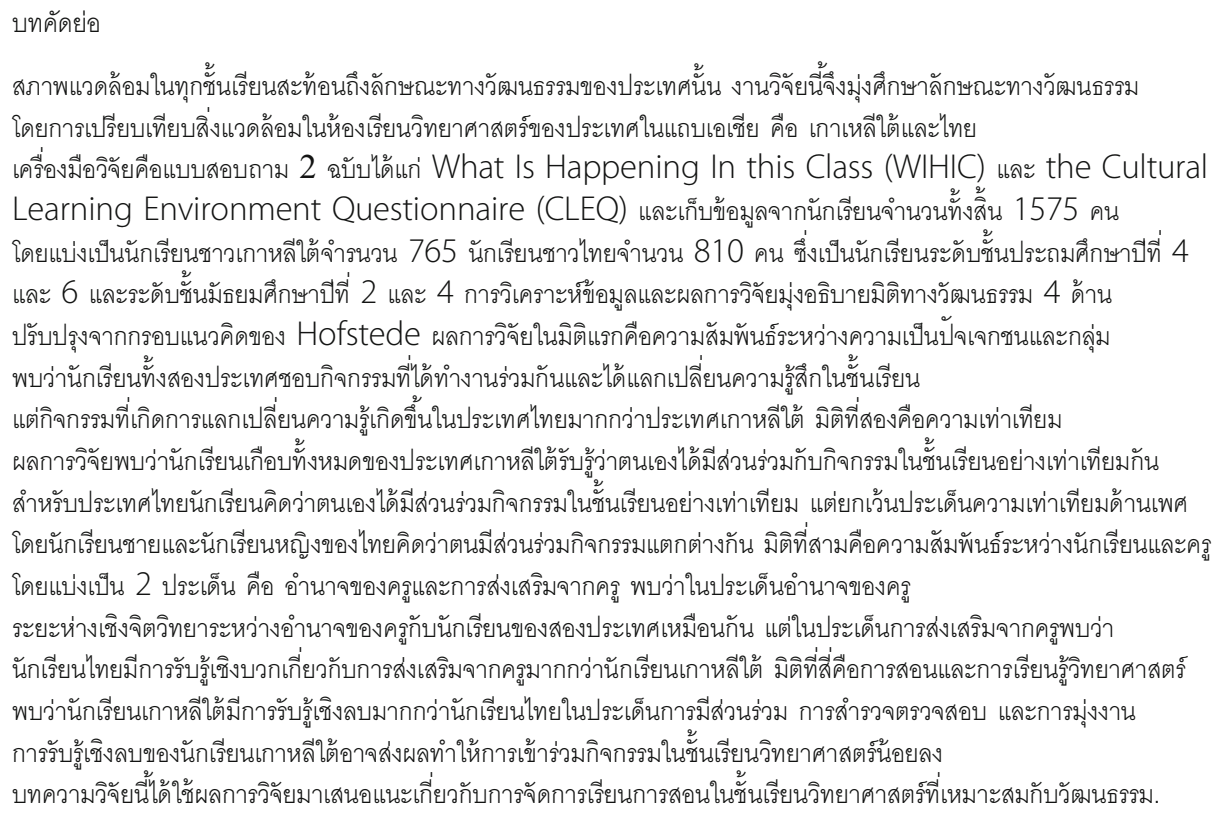

\section{Introduction}

Learning takes place through social interactions in sociocultural contexts including language, social relations, and community culture (Lave and Wenger 1991; Vygotsky 1978). Because of the social nature of learning, the sociocultural contexts in which students interact have a considerable influence on their learning process (Vygotsky 1978). 
Thus, to understand what and how students learn, it is essential to investigate the sociocultural contexts where learning takes place as well as their impact on learning.

In an effort to understand sociocultural contexts and their impact on learning, an international research community interested in the learning environments of classrooms (hereafter called "classroom environment") has been firmly established over the past few decades (e.g., Fraser 1998, 2002). A classroom environment refers to all of the physical, psychological, and social contexts affecting the growth of students in classrooms (Fraser 1998). A classroom environment has been closely linked to various sociocultural factors influencing students' psyches and outcomes in classrooms (Fraser 1998). It is thus important to identify how students perceive their classroom environment and which factors are related to students' perceptions.

Every classroom environment reflects the particular cultural and educational features of the society in which it is located (Hofstede 1986; Aldridge et al. 2000). Focusing on the unique cultural features of each society, Hofstede (1986) delineated the impact of these cultural features on teaching and learning. According to Hofstede's theory, the core differences among cultures can be presented as the four main cultural dimensions: individualism vs collectivism; power distance; uncertainty avoidance; masculinity and femininity. For example, Korea, which is a culture in Asia, has a collectivist culture, a large power gap, and a strong tendency to avoid ambiguity. He argued that the cultural features of each society are reflected in its teaching and learning process (Hofstede 1986). Along these lines, the classroom environment of every society also has its own unique characteristics and works in its own way depending on cultural features (Aldridge et al. 2000; Singh and McNeil 2014). Thus, student reactions and responses to classroom environments need to be analyzed and interpreted in terms of a society's cultural features (Aldridge et al. 1999).

In science education research, much attention has been given to identifying the unique features of science classroom environments in each country (e.g., Aldridge et al. 1999; Fraser 1998, 2002; Khine and Fisher 2004). In particular, the features of science classroom environments in Asia have been investigated by comparing Asian and Western science classrooms (Aldridge et al. 1999; Khine and Fisher 2004). For example, Aldridge and Fraser (2000) compared classroom learning environments in Australia and Taiwan. They reported that Australian students perceived their learning environments more favorably than did Taiwan students. Meanwhile, Khine and Fisher (2004) reported that students taught by Asian teachers enjoyed their science lessons less than those taught by Western teachers. In their study, students perceived that Asian teachers were stricter and had less favorable relationships with students than Western teachers (Khine and Fisher 2004). As illustrated by the above studies, most previous studies investigating Asian science classrooms have tended to focus on comparing the features of Asian classrooms to Western classrooms.

However, these kinds of comparisons between Eastern and Western regions may have some limitations in terms of understanding the Eastern and Western science classrooms themselves. In many cases, while the Asian region is often reported to have one culture, in reality various cultures coexist with each other in the Asian region (Kim 2011). For example, although Korea, China, and Japan belong to similar Confucian cultures in East-Asian region, it has been reported that their social beliefs, human relationships, family consciousness, and perception of quality of life are quite different (Kim 2011;). In order 
to investigate the unique traits of Asian science classrooms in detail, it is essential to identify and understand both cultural differences and homogeneity within Asian cultures (Song 2013; Sumida et al. 2016).

In this study, we examine two Asian countries: Korea and Thailand. While both countries are located in Asia, Korea is in East Asia while Thailand is in Southeast Asia. In terms of cultural features, the two countries have differences as well as similarities. For example, both countries belong to cultures that have large power distance, collectivism, and strong uncertainty avoidance (Hofstede 1986). While they have traditionally been influenced by both Buddhist and Confucian cultures, Korea has been more influenced by Confucian culture whereas Thailand has been more influenced by Buddhist culture (Jung 2013). The two countries also have different political systems, religions, and climates (Jung 2013).

Together with these general cultural backgrounds, science classrooms in the two countries also have their own cultural traits. There have also been reported differences and commonalities in science education. For example, differences between East Asian and Southeast Asian students have been revealed in international comparison studies such as PISA and TIMSS (e.g., OECD 2016). In the PISA 2015 science assessment, Korea ranked 11th in performance while Thailand ranked 54th (OECD 2016). However, in motivation for learning science in the PISA 2015, Korea's score was - 0.14 points, well below the OECD average, while Thailand received a score of 0.42, well above the OECD average (OECD 2016).

To explore why these differences and commonalities occur in science education of Korea and Thailand, it is necessary to examine the science classrooms of both countries from a cultural perspective and provide educational implications. Thus, this study compares Korean and Thai students' perceptions about science classroom environments and then discusses commonalities and differences between the two countries with their own cultural features. Concretely, the research questions of this study are as follows.

1. What are the similarities between the science classroom environments of Korea and Thailand with a focus on their cultural features?

2. What are the differences between the science classroom environments of Korea and Thailand with a focus on their cultural features?

\section{Theoretical backgrounds}

How does the culture of a society affect classrooms? In this study, the cultural matrix of social psychology suggested by Fiske et al. (1998) was selected as a theoretical framework to analyze the relationships between a culture and classroom environments belonging to that culture. The cultural matrix of social psychology framework posits that a culture and the human psyche are complementary with each other. The cultural features of a society enable, inform, and constrain individual human psyches and their actions through customs, norms, language, and social systems. However, at the same time, the thoughts and actions of each person can interpret, reproduce, and transform the cultural realities. That is, a culture and the humans' psyches or thoughts in the culture are constructed in their mutual relationships. The mutual constructions of culture and human psyches can be visualized as shown in Fig. 1, which concretely shows the mutual relationships between each dimension represented by arrows connecting each dimension. 


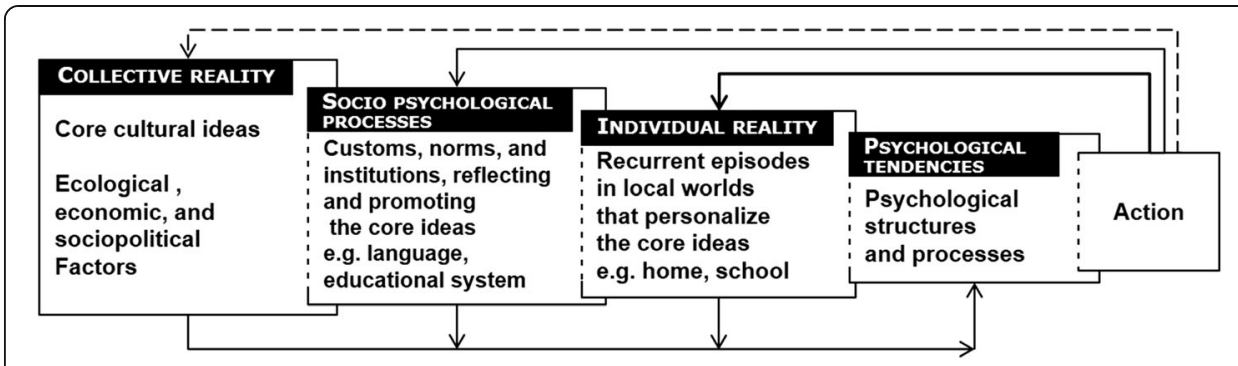

Fig. 1 The cultural matrix of social psychology (Fiske et al. 1998)

Similarly, in these mutual relationships, the cultural and educational values of a society are reflected in the educational norms, educational institutions or policies, and teaching and learning practices (Geertz 1973). The reflection of customs, norms, institutions, and policies in teaching and learning processes can be revealed through classroom interactions, social relationships, and individual members' thoughts and feelings in classrooms. At the same time, the thoughts and actions of the classroom members can change their daily lives in the science classroom, which affects social systems and ultimately leads to the reproduction of the culture (Sewell Jr 1999). In this sense, the students' perceptions of their science classrooms can be one of the factors that both shape the culture and reveal the cultural traits reflected in the science classroom (Chang et al. 2015). In other words, interpreting the students' thoughts on their science classrooms using cultural characteristics can be used as an alternative window to show the cultural characteristics of each country.

Meanwhile, in an effort to investigate the cultures of each country, Hofstede (1983) posited that there were four types of common problems generated in every culture: relationships between individuals and groups, beliefs about masculinity and femininity, relationships with power, and responses to uncertainty. Based on these common problems, he suggested four cultural dimensions that could be used to reveal the core differences among cultures: individualism vs collectivism, masculinity as femininity, power distance, and uncertainty avoidance. The individualism vs collectivism dimension refers to the extent to which a person belongs to the "in group" in a society. The masculinity vs femininity dimension refers the distinctions between the social roles of men and women in a society. The power distance dimension refers to the extent to which less powerful people feel power inequality with others. The uncertainty avoidance dimension refers to the extent to which people feel uncomfortable in response to unstructured or unclear situations. Hofstede (1986) argued that these four cultural dimensions can be general criteria that show the core cultural ideas of each country.

Based on the above common problems and cultural dimensions, we assumed that the features of the four cultural dimensions would be also reflected in the sociocultural environments of classrooms in aspects such as social relationships and interactions. As shown in Table 1, the four cultural dimensions of Hofstede were reinterpreted as general criteria to show the cultural features of the science classrooms in this study. In other words, we restructured the Hofstede's cultural dimensions in terms of the context of the science classroom environment so that we could use them as criteria to analyze cultural features. 
Table 1 The criteria re-structured for analyzing the cultural features of classrooms based on Hofstede's theory

\begin{tabular}{|c|c|c|}
\hline \multicolumn{2}{|l|}{ Hofstede (1983) } & \multirow{2}{*}{$\begin{array}{l}\text { Cultural dimensions in science classrooms } \\
\text { (the analysis criteria of this study) }\end{array}$} \\
\hline Common problems & Cultural dimensions & \\
\hline $\begin{array}{l}\text { Relationships between } \\
\text { individuals and groups }\end{array}$ & $\begin{array}{l}\text { Individualism } \\
\text { vs collectivism }\end{array}$ & Relationships between individuals and groups \\
\hline $\begin{array}{l}\text { Conceptions of masculinity } \\
\text { and femininity }\end{array}$ & $\begin{array}{l}\text { Masculinity } \\
\text { vs femininity }\end{array}$ & $\begin{array}{l}\text { Gender equity of social roles and participation } \\
\text { in science activities }\end{array}$ \\
\hline Relationships with power & Power distance & Relationships between students and science teachers \\
\hline Response to the uncertainty & $\begin{array}{l}\text { Uncertainty } \\
\text { avoidance }\end{array}$ & $\begin{array}{l}\text { Features of science teaching and learning processes, } \\
\text { including uncertain situations }\end{array}$ \\
\hline
\end{tabular}

In sum, as shown in Table 1, we used the four cultural dimensions to analyze the science classroom environments reflecting the cultural features of Korea and Thailand. In other words, the data from science classroom environments were interpreted using these four cultural dimensions as analytic criteria.

\section{Research method}

Instruments: What is happening in this class and cultural learning environment questionnaire The two learning environment instruments, the Cultural Learning Environment Questionnaire (CLEQ) and What Is Happening in This Class (WIHIC) were administered in this study. In this study, we consider them useful and appropriate instruments to reflect the cultural traits of each country. Each instrument has its own advantages in revealing cultural traits, but the foci of the two instruments are different.

The CLEQ is a specialized instrument that extracts culturally sensitive factors from various scales in the previous instruments. As described in Table 2, the CLEQ is composed of seven scales: equity, collaboration, deference, competition, teacher authority, modeling, and congruence. According to Fisher and Waldrip (1997, 1999), who developed this instrument, each scale in the CLEQ is associated with Hofstede's theory: The collaboration and competition scales are related to the individualism vs collectivism dimension; the equity scale is related to the masculinity vs femininity dimension; the teacher authority scale is related to the power distance dimension; and the deference, modeling, and congruence scales are related to the uncertainty avoidance dimension.

Table 2 Descriptions of the scales of CLEQ (Fisher and Waldrip 1999)

\begin{tabular}{|c|c|c|}
\hline Cultural dimensions & Scales & Description \\
\hline \multirow[t]{2}{*}{$\begin{array}{l}\text { Individualism } \\
\text { vs collectivism }\end{array}$} & Collaboration & $\begin{array}{l}\text { The extent to which students perceive that they collaborate with } \\
\text { other students rather than act as individuals }\end{array}$ \\
\hline & Competition & The extent to which the students are competitive with each other \\
\hline $\begin{array}{l}\text { Masculinity } \\
\text { vs femininity }\end{array}$ & Equity & $\begin{array}{l}\text { The extent to which students perceive that boys and girls are } \\
\text { treated equally }\end{array}$ \\
\hline Power distance & $\begin{array}{l}\text { Teacher } \\
\text { authority }\end{array}$ & $\begin{array}{l}\text { The extent to which students perceive that the teacher has authority } \\
\text { in the classroom }\end{array}$ \\
\hline \multirow{3}{*}{$\begin{array}{l}\text { Uncertainty } \\
\text { avoidance }\end{array}$} & Deference & The extent to which students feel that they defer to the opinions of others \\
\hline & Modeling & $\begin{array}{l}\text { The extent to which the students expect to learn by a process of } \\
\text { modeling }\end{array}$ \\
\hline & Congruence & $\begin{array}{l}\text { The extent to which the students perceive learning at school matches } \\
\text { their learning at home }\end{array}$ \\
\hline
\end{tabular}


This shows that the CLEQ is a good way to use Hofstede's model to do cultural interpretation.

WIHIC was also selected in order to look at the cultural traits of students who participate in science classrooms. WIHIC is a well-known instrument that focuses in particular on salient factors influencing students' psyches. As shown in Table 3, WIHIC has seven scales: student cohesiveness, teacher support, involvement, investigation, task orientation, cooperation, and equity. WIHIC, developed by Fraser et al. (1996), consists of scales that were carefully selected as factors strongly correlated with students' cognitive and affective outcomes. Thus, WIHIC reflects the socio-psychological factors of science classrooms relatively well compared to other instruments (Fraser 1998, 2002). In addition, WIHIC has proven its validity and reliability through its wide use in many different countries (e.g., Dorman 2003; Dorman et al. 2006; Fraser 2002). For these reasons, WIHIC was selected as one of the most useful and appropriate instruments to reveal cultural traits.

Specifically, these two instruments were reframed as shown in Table 4 to focus on the cultural dimensions in science classrooms. Concretely, each scale of the two instruments was re-categorized based on the cultural dimensions in science classrooms. However, in the process of re-categorization of each scale, the foci of some dimensions were expanded slightly depending on the meaning of the scale in the instrument. For example, in the gender equity dimension, the equity scale of the CLEQ deals with gender issues in science classrooms; however, the equity scale of WIHIC deals with the general equity issue in science classrooms. Thus, by using both, we aimed at discussing not only the gender equity issue using the CLEQ results but also the social equity issue using the WIHIC results. Similarly, in the CLEQ, the deference, modeling, and congruence scales deal with the uncertainty situations in teaching and learning processes. However, in WIHIC, the involvement, investigation, and task orientation scales deal with situations in science teaching and learning that are more general. Thus, by using both we were able to analyze the students' responses and actions in science teaching and learning processes that include some uncertainty situations.

Finally, as shown in Table 4, the results of each scale were analyzed and presented using the four cultural dimension perspectives. For example, the collaboration, competition, student cohesiveness, and cooperation scales were analyzed together in the relationships between individuals and groups.

Table 3 Descriptions of the scales of WIHIC (Aldridge et al. 1999)

\begin{tabular}{ll}
\hline Scales & Description \\
\hline Student cohesiveness & The extent to which students know, help, and are supportive of one another \\
Teacher support & The extent to which the teacher helps, befriends, trusts, and is interested in students \\
Involvement & The extent to which students have attentive interest, participate in discussions, \\
perform additional work, and enjoy the class & The emphasis on the skills and processes of inquiry and their use in problem solving \\
Investigation & $\begin{array}{l}\text { The investigation } \\
\text { the subject matter } \\
\text { Task orientation }\end{array}$ \\
The extent to which students cooperate rather than compete with one another \\
in learning tasks \\
The extent to which students are treated equally by the teacher
\end{tabular}


Table 4 Re-categorization of scales in WIHIC and CLEQ

\begin{tabular}{lll}
\hline Cultural dimensions in science classrooms (in this study) & Scales of CLEQ & Scales of WIHIC \\
\hline Relationships between individuals and groups & Collaboration & Student cohesiveness \\
& Competition & Cooperation \\
$\begin{array}{l}\text { Equity (including gender) of social roles and } \\
\text { participation in science activities }\end{array}$ & Equity (including gender) & Equity \\
Relationships between students and science teachers & Teacher authority & Teacher support \\
$\begin{array}{l}\text { Features of science teaching and learning processes } \\
\text { (including uncertainty situations) }\end{array}$ & $\begin{array}{l}\text { Deference } \\
\text { Modeling }\end{array}$ & $\begin{array}{l}\text { Involvement } \\
\text { Investigation }\end{array}$ \\
& Congruence & Task orientation \\
\hline
\end{tabular}

In addition, a review of the descriptions of items in the two questionnaires showed that the foci of the two questionnaires were slightly different. WIHIC items ask about perceptions of teacher and student behavior, such as teacher support and student involvement. On the other hand, most statements in CLEQ items start with "I like" or "I feel," i.e., students are asked to respond about their psychological tendencies. WIHIC questions focus more on the classroom context, including teachers' and students' traits, while CLEQ questions focus more on the individual student psyches (Chang et al. 2015). Because the different foci of these two questionnaires may show different aspects of cultural traits in science classrooms, WIHIC and CLEQ can complement each other.

Based on these considerations, this study chose WIHIC and CLEQ among many other similar instruments. The 56-item version of WIHIC and the 35-item version of CLEQ were translated, back-translated, and confirmed. Initially, the two questionnaires were translated into two languages, Korean and Thai, by the members of this study in each country. The Korean and Thai versions of WIHIC and CLEQ were then back-translated into English by other researchers who were not involved in the original translation. Lastly, one fluent English-speaking member checked the back translations and made the appropriate corrections for some items in order to convey the same meaning of the original English version. Every item in the two instruments used a five-point Likert type scale $(1=$ disagree to $5=$ agree $)$.

\section{Data collection and analysis}

This study was carried out in 2014 with 1575 students from Korean and Thai schools. The students were selected from Grades 4, 6, 8, and 10 in both countries. Table 5 shows the sample size by grade level, country, and gender.

The data were analyzed in order to examine the reliability, validity, and factor structure of the two instruments in both countries. The internal consistency of each scale was checked using the alpha reliability coefficient. The mean correlation of a scale with other scales was used as a convenient index of the discriminant validity, while a series of factor analyses was performed to examine the internal structure of each instrument. The ability to differentiate between student perceptions in different classrooms was evaluated by conducting a one-way ANOVA for each scale with class membership as the main effect. Lastly, the data were also analyzed to compare the means and the standard deviations of each scale of the two questionnaires. A $t$-test and a one-way ANOVA for each scale were performed in order to examine which scales were significantly different between countries, genders, and grades. 
Table 5 Description of sample by grade level, country, and gender ( $N=1575$ students)

\begin{tabular}{|c|c|c|c|c|c|c|c|c|c|}
\hline \multirow[t]{2}{*}{ The grade of the respondents } & \multicolumn{3}{|l|}{ Korea } & \multicolumn{3}{|c|}{ Thailand } & \multicolumn{3}{|c|}{ Korea \& Thailand } \\
\hline & Boys & Girls & Total & Boys & Girls & Total & Boys & Girls & Total \\
\hline Grade 4 & 72 & 86 & 158 & 61 & 100 & 161 & 133 & 186 & 319 \\
\hline Grade 6 & 89 & 81 & 170 & 56 & 145 & 201 & 145 & 226 & 371 \\
\hline Grade 8 & 123 & 84 & 207 & 68 & 169 & 237 & 191 & 253 & 444 \\
\hline Grade 10 & 166 & 64 & 230 & 58 & 153 & 211 & 224 & 217 & 441 \\
\hline Total & 450 & 315 & 765 & 243 & 567 & 810 & 693 & 882 & 1575 \\
\hline
\end{tabular}

\section{Implementation of science curriculums in two countries: Korea and Thailand}

In Korea, students learn science as a compulsory subject for 8 years (from Grades 3 to 10) according to the centralized National Science Curriculum. Based on the National Science Curriculum, government-authorized science textbooks (one textbook for elementary schools and several textbooks for secondary schools) have been developed and used in every science classroom across the country. Thus, the contents and levels, and often even the ways, of science learning in schools and classrooms tend to be uniform and controlled evenly across the country. However, because of recent attempts to decentralize education, starting with the 2009 National Science Curriculum, each school has been expected to reorganize and implement their own school-based science curriculum based on the National Curriculum. The National Curriculum gives the lesson time and the content of the subject for each grade band. However, the lesson schedule of each school can be organized and managed differently depending on conditions at the school.

In Thailand, students learn science as a compulsory subject over 12 years of basic education: from Grades 1 to 6 in primary education and from Grades 7 to 12 in secondary education. Like Korea, because education is decentralized, science textbooks are developed by both the government and private companies. Teachers are free to use textbooks developed by any qualified company. However, government-authorized science textbooks are used in the majority of science classrooms, particularly in secondary education. Similar to the Korean science curriculum, the Thai government also aims to decentralize education, and individual schools can also develop their own curriculum based on their own conditions. The National Curriculum provides the content of each subject and the indicators of student learning at each grade level. However, the lesson schedule of each school can be arranged differently depending on school context (Faikhamta and Ladachart 2016).

\section{Validation of Korean and Thai versions of WIHIC and CLEQ}

As the first step in the validation of WIHIC and CLEQ, a principal component factor analysis followed by varimax rotation was used to check the factor structure of the Korean and Thai versions of the two questionnaires. The factor analysis resulted in the acceptance of two versions of the two questionnaires. Table 15 in Appendix 1 and Table 16 in Appendix 2 show the factor loadings obtained from 1575 students' responses in Korea and Thailand. All factor loadings with less than 0.3, the conventionally accepted value, were omitted. The factor loadings for almost all items were more than 0.3 on the a priori scale except three items in WIHIC and one item in CLEQ. The a priori factor 
structures of the final versions of the instruments were confirmed as depicted in Table 15 in Appendix 1 and Table 16 in Appendix 2.

The data were also analyzed to evaluate the reliability and validity of the instruments. In order to examine the internal consistency reliability of each scale in the questionnaires, Cronbach's alpha coefficient was used. As shown in Tables 6 and 7, in this study, the alpha reliability ranged from 0.81 to 0.92 for WIHIC and from 0.70 to 0.92 for CLEQ. These values were high enough to confirm internal consistency.

Lastly, one of the important features of a classroom environment questionnaire is that the instrument can differentiate between classrooms. In other words, classroom environment studies premise that students' perceptions in the same classroom would be relatively similar. Thus, a one-way analysis of variance (ANOVA) using class membership as the main effect was analyzed in order to assess the ability to differentiate between students' responses in different classrooms. Similar to previous studies (Aldridge and Fraser 2000; Kim et al. 1999), eta ${ }^{2}$ statistics were depicted as an index of this ability in Tables 6 and 7. The proportion of variance in scale scores explained by class membership (i.e., eta ${ }^{2}$ ) ranged from 0.05 to 0.14 for WIHIC and from 0.00 to 0.09 for CLEQ. These figures are relatively low, indicating that the science classroom environments are quite similar in each country. Similar results showing little difference among Korean science classrooms were reported in a previous study investigating Korean science classrooms (Kim et al. 2000).

\section{Results}

The first cultural dimension: Relationships between individuals and groups in science classrooms The first cultural dimension, relationships between individuals and groups in science classrooms, was investigated through the collaboration and competition scales in CLEQ and the student cohesiveness and cooperation scales in WIHIC. Overall, among four scales, there were no significant differences in the collaboration and student cohesiveness scales, while there were statistically significant differences in the competition and cooperation scales as shown in Table 8.

Firstly, as for the results of CLEQ, the collaboration scales received high scores while the competition scales received low scores in both countries This means that for the students from both countries, participating as members of a group is considered more important than performing better than others. However, the mean value of the competition scale in Thailand was slightly higher than that in Korea. This means that Thai students perceived that they are a bit more competitive than Korean students in their

Table 6 Cronbach's alpha coefficient, mean correlation, and analysis of variance results for the Korean and Thai versions of WIHIC

\begin{tabular}{|c|c|c|c|c|c|c|c|c|c|c|c|c|c|c|}
\hline \multirow[t]{2}{*}{ Item No. } & \multicolumn{2}{|c|}{$\begin{array}{l}\text { Student } \\
\text { cohesiveness }\end{array}$} & \multicolumn{2}{|c|}{$\begin{array}{l}\text { Teacher } \\
\text { support }\end{array}$} & \multicolumn{2}{|c|}{ Involvement } & \multicolumn{2}{|c|}{ Investigation } & \multicolumn{2}{|c|}{ Task orientation } & \multicolumn{2}{|c|}{ Cooperation } & \multicolumn{2}{|c|}{ Equity } \\
\hline & Kor & Thai & Kor & Thai & Kor & Thai & Kor & Thai & Kor & Thai & Kor & Thai & Kor & Thai \\
\hline $\begin{array}{l}\text { Alpha } \\
\text { coefficient }\end{array}$ & .84 & .81 & .92 & .87 & .92 & .86 & .95 & .88 & .92 & .85 & .87 & .92 & .92 & .85 \\
\hline $\begin{array}{l}\text { Mean } \\
\text { correlation }\end{array}$ & .50 & .51 & .52 & .49 & .61 & .53 & .56 & .56 & .55 & .54 & .57 & .55 & .54 & .52 \\
\hline $\begin{array}{l}\text { ANOVA } \\
\text { results (eta²) }\end{array}$ & .11 & .06 & .14 & .09 & .12 & .05 & .09 & .06 & .12 & .08 & .12 & .08 & .10 & .04 \\
\hline
\end{tabular}


Table 7 Cronbach's alpha coefficient, mean correlation, and analysis of variance results for the Korean and Thai versions of CLEQ

\begin{tabular}{|c|c|c|c|c|c|c|c|c|c|c|c|c|c|c|}
\hline \multirow[t]{2}{*}{ Item No. } & \multicolumn{2}{|c|}{ Equity } & \multicolumn{2}{|c|}{ Collaboration } & \multicolumn{2}{|c|}{ Teacher authority } & \multicolumn{2}{|c|}{ Competition } & \multicolumn{2}{|c|}{ Deference } & \multicolumn{2}{|c|}{ Modeling } & \multicolumn{2}{|c|}{ Congruence } \\
\hline & $\overline{\text { Kor }}$ & Thai & $\overline{\text { Kor }}$ & Thai & $\overline{\text { Kor }}$ & Thai & $\overline{\text { Kor }}$ & Thai & Kor & Thai & $\overline{\text { Kor }}$ & Thai & Kor & Thai \\
\hline $\begin{array}{l}\text { Alpha } \\
\text { coefficient }\end{array}$ & .85 & .70 & .92 & .76 & .82 & .77 & .78 & .82 & .79 & .78 & .87 & .71 & .88 & .76 \\
\hline $\begin{array}{l}\text { Mean } \\
\text { correlation }\end{array}$ & .23 & .36 & .28 & .39 & .24 & .36 & .25 & .34 & .34 & .43 & .35 & .42 & .32 & .39 \\
\hline $\begin{array}{l}\text { ANOVA } \\
\left.\text { results (eta }{ }^{2}\right)\end{array}$ & .06 & .02 & .08 & .04 & .08 & .05 & .04 & .01 & .06 & .04 & .05 & .00 & .09 & .05 \\
\hline
\end{tabular}

science classrooms. This is an unexpected result, because Korea is widely known around the world for its competitive educational system (Sorensen 1994). Considering that the result of CLEQ refers to the students' psychological traits, the students in both countries prefer collaborative activities to individual or competitive activities regardless of their competitive educational context, especially in Korea.

Meanwhile, in WIHIC results, the student cohesiveness scale is more related to emotional relationships, while the cooperation scale is more related to cognitive relationships. As a result of WIHIC, the mean value of the student cohesiveness scale was the highest score in both countries and there was no statistically significant difference between them. This means that students in science classrooms are intimate emotionally with each other. On the other hand, in the cooperation scale, there was a significant difference between the two countries. The mean score of Thailand was statistically higher than the mean score of Korea. In other words, in Thailand, both emotional and cognitive collaborative relationships were established well in science classrooms. However, in Korean science classrooms, the emotional relationship was reported to be high but the cognitive relationship was reported to be relatively low.

The second cultural dimension: Equity (including gender) of social roles and participation in science activities

The second cultural dimension in science classrooms, gender equity of social roles and participation in science activities, was investigated through the (gender) equity scale of CLEQ and the equity scale of WIHIC. The features related to equity in science classrooms are as shown in Table 9.

In CLEQ results, it was reported in both countries that the gender equity scales received the highest scores among other CLEQ scales; however, the mean value of Korean

Table 8 A comparison of the first cultural dimension between Korea and Thailand

\begin{tabular}{llllll}
\hline Instruments & Related scales & \multicolumn{2}{c}{ M (SD) } & $t$ & Effect size (Cohen's d) \\
\cline { 3 - 5 } & & Korea & Thailand & & \\
\hline CLEQ & Collaboration & $3.95(1.06)$ & $3.95(.76)$ & 0.02 & 0.10 \\
& Competition & $3.15(1.06)$ & $3.25(.96)$ & $-2.10^{*}$ & \\
\multirow{2}{*}{ WIHIC } & Student cohesiveness & $3.80(.66)$ & $3.83(.60)$ & -1.05 & 0.42 \\
& Cooperation & $3.56(.90)$ & $3.89(.66)$ & $-8.42^{* *}$ & \\
\hline
\end{tabular}

${ }^{*} p<.05,{ }^{* *} p<.01$ 
Table 9 A comparison of the second cultural dimension between Korea and Thailand

\begin{tabular}{llllll}
\hline Instruments & Related scales & \multicolumn{2}{c}{ M (SD) } & \multirow{2}{*}{ Effect size (Cohen's d) } \\
\cline { 3 - 4 } & & Korea & Thailand & & \\
\hline CLEQ & (Gender) Equity & $4.66(.66)$ & $4.28(.70)$ & $11.03^{* *}$ & 0.56 \\
WMIC & Equity & $3.73(.88)$ & $3.78(.77)$ & -1.22 & \\
\hline
\end{tabular}

${ }^{*} p<.05,{ }^{* *} p<.01$

students' scores was significantly higher than those of Thai students. Korean students have a greater belief that "girls and boys" are treated equally in science classrooms than Thai students do. That is, the equity between girls and boys was perceived to be better in Korean science classrooms. These results reflect the cultural differences of the two countries in terms of gender equity. Culturally, Thai girls are often taught to have "good" manners and keep quiet in the male-centered culture stemming from Confucianism (Cheevapitakpol 2014). In order to be "good" girls, they are asked not to express their feelings too much. On the other hand, even though Korea is also known to be influenced by the Confucian culture in which gender discrimination is prevalent (Cheevapitakpol 2014), Korean girls and boys report that they are treated rather equally in science classrooms, as shown in the Korean results.

In the results of the equity scale in WIHIC, the scores of the two countries were both reported to be more than 3.7 points and there was no statistically significant difference between them. These results show that students participate fairly in science classrooms in both countries. It is noteworthy that these results are in contrast to the results of CLEQ related to the gender equity issue. In other words, considering the WIHIC results with the CLEQ results, Korean students answered that they participated equally in their science classrooms regardless of gender and other factors. Thai students responded that they participated equally overall except for the gender aspect.

Gender is one of the key indicators that reveal cultural differences among countries (Hofstede 1986). For figuring out the detailed features related to gender in science classrooms, we tried to examine gender differences in the results of each instrument as shown in Tables 10 and 11. Firstly, in examining the gender differences of CLEQ, there were significant differences between boys and girls in the deference and competition scales (Table 10). Except for these two scales, there was not much difference in the cultural tendencies between boys and girls.

As shown in Table 10, in the deference scales of both countries, the mean scores were significantly higher for boys than for girls. The results mean that boys tended to follow others' opinions or correct answers more than girls did. On the other hand, this scale refers to the tendencies to avoid uncertainty situations. Thus, this result may indicate that boys in the two countries have a greater tendency to avoid uncertain situations than girls do in science classrooms. For example, boys may consider it important to give the "correct" answers in science inquiry and argumentation. Meanwhile, in the competition scale of Thai results, the mean score of boys was higher than the girls' score. This indicates that Thai boys were more competitive than Thai girls. The competition scale in Korea showed no significant differences between boys and girls.

Next, based on the WIHIC results, Table 11 shows the differences between the two countries in terms of gender difference. In Korea, there was no significant difference between boys' and girls' answers in all scales. On the other hand, in Thailand, there were many 
Table 10 Gender differences of CLEQ results in Korea and Thailand

\begin{tabular}{|c|c|c|c|c|c|c|c|c|}
\hline \multirow{3}{*}{ Scales } & \multicolumn{4}{|l|}{ Korea } & \multicolumn{4}{|l|}{ Thailand } \\
\hline & \multirow{2}{*}{$\begin{array}{l}\text { Boys } \\
\text { M (SD) }\end{array}$} & \multirow{2}{*}{$\begin{array}{l}\text { Girls } \\
M(S D)\end{array}$} & \multirow[t]{2}{*}{$t$} & \multirow{2}{*}{$\begin{array}{l}\text { Effect size } \\
\text { (Cohen's d) }\end{array}$} & \multirow{2}{*}{$\frac{\text { Boys }}{M(S D)}$} & \multirow{2}{*}{$\begin{array}{l}\text { Girls } \\
\text { M (SD) }\end{array}$} & \multirow[t]{2}{*}{$t$} & \multirow{2}{*}{$\begin{array}{l}\text { Effect size } \\
\text { (Cohen's d) }\end{array}$} \\
\hline & & & & & & & & \\
\hline Collaboration & $3.92(1.10)$ & $4.00(1.00)$ & -1.01 & & $3.95(.83)$ & $3.96(.72)$ & -0.21 & \\
\hline Competition & $3.15(1.00)$ & $3.16(1.00)$ & -0.18 & & $3.40(1.01)$ & $3.19(.94)$ & $2.86^{* *}$ & 0.22 \\
\hline Gender equity & $4.63(.71)$ & $4.70(.57)$ & -1.68 & & $4.20(.80)$ & $4.32(.65)$ & -1.92 & \\
\hline Teacher authority & $3.66(.86)$ & $3.60(.86)$ & 0.96 & & $3.79(.84)$ & $3.68(.78)$ & 1.80 & \\
\hline Deference & $3.19(.96)$ & $2.93(.96)$ & $3.80^{* *}$ & 0.27 & $3.20(.93)$ & $2.90(.97)$ & $3.95^{* *}$ & 0.31 \\
\hline Modeling & $3.60(.93)$ & $3.72(.93)$ & -1.84 & & $3.72(.82)$ & $3.64(.86)$ & 1.30 & \\
\hline Congruence & $3.55(.92)$ & $3.62(.92)$ & -0.93 & & $3.85(.82)$ & $3.79(.75)$ & 1.04 & \\
\hline
\end{tabular}

significant differences depending on gender. Specifically, Thai boys perceived science classrooms more favorably than did Thai girls in the teacher support, involvement, and investigation scales, while Thai girls considered science classrooms more favorably in the task orientation and cooperation scales. In other words, Thai boys were more active and supported by teachers while Thai girls were more task oriented and cooperative in their science classrooms. These gender-related differences between the two countries may have different effects on girls' and boys' participation, interaction, and scientific practices in their classrooms.

Meanwhile, it is interesting that, compared to the past results in two previous Korean studies, the gender gap of students' thought about their science classrooms has decreased gradually. As shown in Table 12, in a 1998 study, Kim et al. (2000) found that there were significant differences in all scales of WIHIC. In a 2010 study (Hong et al. 2010), it was reported that there were significant differences in only two scales of cohesiveness and cooperation. Finally, in the results collected in 2014 of this study, there were no difference in all scales. In sum, the differences among data collected in Korea in 1998, 2010, and 2014 show that the gender differences in students' perceptions of science classrooms appear to have disappeared. In fact, in order to increase the scientific participation of female students, various efforts have been made in Korea (Choi 2003; Jhun and Shin 2004). These efforts may have helped to improve gender equality in Korean science classrooms.

Table 11 Gender differences in WIHIC results in Korea and Thailand

\begin{tabular}{|c|c|c|c|c|c|c|c|c|}
\hline \multirow{3}{*}{ Scales } & \multicolumn{4}{|l|}{ Korea } & \multicolumn{4}{|l|}{ Thailand } \\
\hline & \multirow{2}{*}{$\begin{array}{l}\text { Boys } \\
\text { M(SD) }\end{array}$} & \multirow{2}{*}{$\begin{array}{l}\text { Gills } \\
M(S D)\end{array}$} & \multirow[t]{2}{*}{$t$} & \multirow{2}{*}{$\begin{array}{l}\text { Effect size } \\
\text { (Cohen's d) }\end{array}$} & \multirow{2}{*}{$\frac{\text { Boys }}{M(S D)}$} & \multirow{2}{*}{$\begin{array}{l}\text { Girls } \\
M(S D)\end{array}$} & \multirow[t]{2}{*}{$t$} & \multirow{2}{*}{$\begin{array}{l}\text { Effect size } \\
\text { (Cohen's d) }\end{array}$} \\
\hline & & & & & & & & \\
\hline Cohesiveness & $3.77(.61)$ & $3.85(.61)$ & -1.60 & & $3.79(.70)$ & $3.85(.55)$ & -1.26 & \\
\hline Cooperation & $3.51(.89)$ & $3.62(.89)$ & -1.69 & & $3.78(.71)$ & $3.93(.63)$ & $-2.84^{* *}$ & 0.23 \\
\hline Equity & $3.69(.88)$ & $3.79(.88)$ & -1.55 & & $3.76(.81)$ & $3.78(.76)$ & -0.29 & \\
\hline Teacher support & $3.15(.87)$ & $3.19(.87)$ & -0.71 & & $3.56(.78)$ & $3.35(.68)$ & $3.61^{* *}$ & 0.30 \\
\hline Involvement & $2.93(.86)$ & $2.84(.86)$ & 1.26 & & $3.24(.79)$ & $3.12(.66)$ & $2.08^{*}$ & 0.17 \\
\hline Investigation & $2.98(.99)$ & $2.96(.99)$ & 0.21 & & $3.43(.80)$ & $3.30(.69)$ & $2.13^{*}$ & 0.18 \\
\hline Task orientation & $3.67(.87)$ & $3.77(.87)$ & -1.49 & & $3.80(.71)$ & $3.95(.62)$ & $-2.81^{* *}$ & 0.23 \\
\hline
\end{tabular}

${ }^{*} p<.05,{ }^{* *} p<.01$ 
Table 12 Gender differences in Korean data collected in 1998, 2010, and 2014

\begin{tabular}{|c|c|c|c|c|c|c|c|c|c|}
\hline \multirow[t]{3}{*}{ Scales } & \multicolumn{3}{|c|}{ Kim et al. (collected in 1998) } & \multicolumn{3}{|c|}{ Hong et al. (collected in 2010) } & \multicolumn{3}{|c|}{ This study (collected in 2014) } \\
\hline & \multirow{2}{*}{$\begin{array}{l}\text { Boys } \\
M\end{array}$} & \multirow{2}{*}{$\begin{array}{l}\text { Girls } \\
M\end{array}$} & \multirow{2}{*}{$\begin{array}{l}\text { Mean } \\
\text { difference }\end{array}$} & \multirow{2}{*}{$\begin{array}{l}\text { Boys } \\
M\end{array}$} & \multirow{2}{*}{$\begin{array}{l}\text { Girls } \\
M\end{array}$} & \multirow{2}{*}{$\begin{array}{l}\text { Mean } \\
\text { difference }\end{array}$} & \multirow{2}{*}{$\begin{array}{l}\text { Boys } \\
M\end{array}$} & \multirow{2}{*}{$\begin{array}{l}\text { Girls } \\
M\end{array}$} & \multirow{2}{*}{$\begin{array}{l}\text { Mean } \\
\text { difference }\end{array}$} \\
\hline & & & & & & & & & \\
\hline Cohesiveness & 35.44 & 37.39 & $-1.95^{* * *}$ & 3.71 & 3.94 & $-0.23^{* * *}$ & 3.77 & 3.85 & -0.08 \\
\hline Cooperation & 31.72 & 33.55 & $-1.83^{* *}$ & 3.21 & 3.42 & $-0.21^{* * *}$ & 3.51 & 3.62 & -0.11 \\
\hline Equity & 32.11 & 29.34 & $2.77^{* * *}$ & 3.15 & 3.25 & -0.1 & 3.69 & 3.79 & -0.1 \\
\hline Teacher support & 26.74 & 22.30 & $4.44^{* * *}$ & 2.53 & 2.46 & 0.07 & 3.15 & 3.19 & -0.04 \\
\hline Involvement & 25.21 & 23.43 & $1.78^{* *}$ & 2.50 & 2.44 & 0.06 & 2.93 & 2.84 & 0.09 \\
\hline Investigation & 25.08 & 22.64 & $2.44^{* * *}$ & 2.51 & 2.39 & 0.12 & 2.98 & 2.96 & 0.02 \\
\hline Task orientation & 34.47 & 33.14 & $1.33^{*}$ & 3.42 & 3.42 & 0 & 3.67 & 3.77 & -0.1 \\
\hline
\end{tabular}

The third cultural dimension: Relationships between students and science teachers

Relationships between students and science teachers, the third cultural dimension in classrooms, were analyzed by using the teacher authority scale in CLEQ and the teacher support scale in WIHIC. The results of these two scales are shown in Table 13.

In the CLEQ results, there was no significant difference between Korea and Thailand in the teacher authority scale. This means that the students in both countries feel a similar degree of power distance from their teachers. According to Hofstede (1991), Korea and Thailand have both been reported as being societies having a "large power distance." In other words, the extent of power distance felt by people with low social status in Korean society is similar to that in Thai society. In the same vein, the results of this study also show that the extent of psychological distance between students and their teachers is similar in the two countries.

As for the WIHIC results, in both countries, the mean scores of the teacher support scale were less than 3.5 points. This means that both Thai and Korean students are not positively aware of teacher support in the science classroom. Furthermore, the mean value of Korean results was significantly lower than that of Thai results, meaning that Korean students perceived they received less support from their teachers than Thai students reported. Students can be supported by their teachers in the classroom in various ways including cognitive, emotional, and social ways. In WIHIC, the items in the teacher support scale ask the cognitive, emotional, and social aspects related to "teacher support," so it is necessary to look into which aspect of teacher support the students need in Korean science classrooms.

Table 13 A comparison of the third cultural dimension between Korea and Thailand

\begin{tabular}{llllll}
\hline Instruments & Related scales & \multicolumn{2}{c}{ M (SD) } & $t$ & Effect size \\
\cline { 3 - 4 } & & & & \\
\cline { 3 - 4 } & & & & \\
(Cohen's d)
\end{tabular}

${ }^{*} p<.05,{ }^{* *} p<.01$ 
The forth cultural dimension: Features of science teaching and learning processes (including uncertainty situations)

For features of science teaching and learning processes, we investigated the deference, modeling, and congruence scales in CLEQ and the involvement, investigation, and task orientation scales in WIHIC. The results of each instrument related to the forth cultural dimension are shown in the following Table 14.

Among the three scales in CLEQ, a significant difference was reported statistically in the congruence scale; however, in the deference and modeling scales there were no significant differences. Concretely, the mean value of Thai students in the congruence scale was significantly higher than the Korean students' score, meaning that Korean students thought that learning in science classrooms was less relevant to learning at home than did Thai students. In particular, the relevance of science to students' personal lives has an impact on promoting students' interest in science (Palmer 2007). Thus, the situation reflected in this result could have a negative effect on Korean students' interest in science and on their practice.

In the results of WIHIC, overall, the mean scores of Thai students were significantly higher than those of Korean students in the three scales. These results indicate that Thai students thought that they were more active and more task-oriented than Korean students. It has been reported that the positive classroom environments improve students' attitudes and interests in science (Fraser 2002). In this context, the negative perceptions about Korean science classroom environments can be considered a cross section showing low engagement in science classrooms.

\section{Conclusion and implication}

In this study, we compared science classroom environments in Korea and Thailand with a focus on their cultural features by administering two well-known instruments developed for science classroom environments, WIHIC and CLEQ, to 1575 primary and secondary students (Grades 4, 6, 8, and 10; similar numbers of students from both Korea and Thailand). This survey showed differences as well as similarities between the two countries, centering on the four cultural dimensions in science classrooms: relationships between individuals and groups, equity (including gender) of social roles and participation in science activities, relationships between students and science teachers, and features of science teaching and learning processes. The survey results are presented and discussed in terms of these cultural dimensions below.

First, in terms of relationships between individuals and groups, it was reported that the students in the two countries had high emotional intimacy in their science classrooms

Table 14 A comparison of the forth cultural dimension between Korea and Thailand

\begin{tabular}{llllll}
\hline Instruments & Related scales & \multicolumn{2}{c}{ M (SD) } & $t$ & $\begin{array}{c}\text { Effect size } \\
\text { (Cohen's d) }\end{array}$ \\
\cline { 3 - 4 } & & Korea & Thailand & & 1.7 \\
\hline CLEQ & Deference & $3.08(.97)$ & $3.00(.97)$ & & \\
& Modeling & $3.65(.94)$ & $3.66(.85)$ & -0.30 & \\
\multirow{2}{*}{ wnnc } & Congruence & $3.58(.97)$ & $3.81(.77)$ & $-5.30^{* *}$ & 0.26 \\
& Involvement & $2.88(.91)$ & $3.16(.70)$ & $-6.63^{* *}$ & 0.35 \\
& Investigation & $2.96(.99)$ & $3.34(.73)$ & $-8.77^{* *}$ & 0.44 \\
& Task orientation & $3.71(.88)$ & $3.91(.64)$ & $-5.21^{* *}$ & 0.26 \\
\hline
\end{tabular}

${ }^{*} p<.05,{ }^{* *} p<.01$ 
and preferred cooperative activities to competitive activities. In other words, the students enjoyed participating as members of their classroom communities. Korea and Thailand have traditionally been typical collectivist cultures. In a collective society, people tend to consider establishing a sense of belonging and the relationship with group members as important (Hofstede 1991). These cultural tendencies can be seen in the characteristics of the science classrooms of the two countries, such as the sense of intimacy with each other and the enjoyment of being a community member reported in this study. Although establishing good emotional relationships with their colleagues was commonly regarded as important in the two countries, cognitive collaborative activities appear to occur differently, in that cognitive collaborative activities were reported to occur more actively in Thai science classrooms than in Korean science classrooms.

Second, when examining the equity (including gender) issue, almost all students in the two countries perceived that they had equal participation and opportunity in their activities in science classrooms. However, in terms of gender equity, a significant difference was reported between the two countries: in Korea, both boys and girls responded that they all participated fairly and had equal competences regardless of gender. On the other hand, in Thailand, the responses of boys and girls were significantly different from each other. Furthermore, the differences between Thai boys and Thai girls were more marked in WIHIC results than in CLEQ results. This means that boys and girls in Thailand have similar cultural tendencies, but they participate in different ways in their classroom environments. For example, Thai boys have more teacher support and more opportunities for participation in inquiry activities, but Thai girls are more encouraged in terms of collaboration and task concentration. That is, culturally, boys and girls in the same science classrooms tend to be encouraged to participate with different emphases on their roles. Another interesting point is that the gender gaps of students' perceptions of Korean science classrooms have continuously decreased, as shown in studies from 1998 (Kim et al. 2000), 2010 (Hong et al. 2010), and the current study data from 2014. The differences in perceptions of boys and girls about participation and opportunities in Korean science classrooms have diminished over time.

Third, in the relationships between students and their teachers, we identified two kinds of relationships: teacher authority and teacher support. In terms of the students' responses to questions about teacher authority, there was no difference between the two countries. However, in terms of teacher support, Thai students reported that they received more support from their teachers than did Korean students. The issues related to teacher support and authority are complicated and are hard to describe in one word. For example, there are multiple levels of teacher support, such as cognitive and emotional support. Similarly, cognitive authority and emotional authority are also different from each other. Therefore, based on the results of this study, an additional qualitative study needs to be conducted. In particular, in Korea, where a lack of support was reported, it is necessary to analyze which aspects of teacher support were not enough and how to supplement them.

Fourth, in looking at the features of science teaching and learning processes, science classroom environments in Korea were significantly worse than those of Thailand in the scales of involvement, investigation, and task orientation. These results may be related to the reality of Korean science education, which has shown a big disparity, with high achievement and low engagement (Song 2013). In addition, Korean students had a greater perception that school science was different from their everyday lives than Thai students did. The Korean students' perceptions may also explain the low engagement of 
Korean students in science learning, because students tend to think that science learning is more valuable when it is connected with everyday life (Palmer 2007). Therefore, policy and practical effort aimed at connecting school science with everyday life are needed.

Focusing on cultural traits in the results of this study can give us some implications for culturally appropriate pedagogies in science classrooms. For example, since both countries have collectivist cultures, students' tendencies related to this collectivism can have an influence on their perceptions of science cooperative activities (Joo et al. 2012). In this study, students in both countries reported considering it important to work together as a group member and showing strong emotional relationships with each other. However, from the perspective of cognitive collaboration, the results of two countries were significantly different, in that in Thai science classrooms, the cognitive collaborations occurred more actively than in Korean science classrooms. These results may indicate that collective cultural features can influence science classroom activities in at least two kinds of collaboration: cognitive and emotional collaboration. In other words, the two types of collaborations should be considered when we construct science lessons reflecting collectivist cultures.

Another implication involves the male-centered culture that stems from Confucianism. Traditionally, the two countries both have a male-centered culture in common (Cheevapitakpol 2014; Chung 1994; Croll 2000); however, this appeared differently in science classrooms of two countries. In particular, in comparison with the past results, the gender differences in students' perceptions of Korean science classrooms has decreased continuously (Kim et al., 2000; Hong et al. 2010). Thai students, however, still participated in science classrooms in different ways depending on gender. To improve the gender equality, Thai teachers need to allow female students to participate more actively and to develop "girl-friendly" science teaching and learning materials. For this, teaching strategies to activate female science education, which were attempted in Korea (Choi 2003; Jhun and Shin 2004), will be helpful to Thai science classrooms. Policy makers as well as teachers can bring our gender-related results to design science lessons by providing equity in science activities.

However, at the same time, these gender equity-related results show, especially the case of Korea, that deep-rooted cultural features can change along with regional conditions and social environments. Although both are in Asia, the science classrooms of the two countries were different depending on the temporal changes and cultural characteristics of each region. In the same vein as these findings, it is true that science classroom environments and the interactions inside science classrooms do reflect the cultural features of different levels. It is difficult to determine any causal factors and relationships among the data of this study and other findings from previous related studies unless we carry out further ambitious and controlled studies.

Nevertheless, this study provides some invaluable data and insights through which we can understand what is going on inside our science classrooms and how similar and different science classrooms are in the two Asian countries. The findings of this study reflect not only the multi-layered on-going cultural landscapes of society but also their continuous changes. To understand the current situations in our school science classrooms more clearly, which must be the firm basis of any meaningful and effective practical improvement of school science education, we believe that studies similar to this need to be further explored with different instruments and with different groups of countries and that a greater number of qualitative studies looking inside science classrooms must be accompanied by this kind of instrument-based quantitative study. 


\section{Appendix 1}

Table 15 Factor loadings for the Korean and Thai versions of WIHIC

\begin{tabular}{|c|c|c|c|c|c|c|c|c|c|c|c|c|c|c|}
\hline \multirow[t]{2}{*}{ Item No. } & \multicolumn{2}{|c|}{$\begin{array}{l}\text { Student } \\
\text { cohesiveness }\end{array}$} & \multicolumn{2}{|c|}{$\begin{array}{l}\text { Teacher } \\
\text { support }\end{array}$} & \multicolumn{2}{|c|}{ Involvement } & \multicolumn{2}{|c|}{ Investigation } & \multicolumn{2}{|c|}{$\begin{array}{l}\text { Task } \\
\text { orientation }\end{array}$} & \multicolumn{2}{|c|}{ Cooperation } & \multicolumn{2}{|c|}{ Equity } \\
\hline & Thai & Kor & Thai & Kor & Thai & Kor & Thai & Kor & Thai & Kor & Thai & Kor & Thai & $\overline{\text { Kor }}$ \\
\hline 1 & .50 & .72 & & & & & & & & & & & & \\
\hline 2 & - & .72 & & & & & & & & & & & & \\
\hline 3 & .63 & .71 & & & & & & & & & & & & \\
\hline 4 & - & .81 & & & & & & & & & & & & \\
\hline 5 & .69 & .80 & & & & & & & & & & & & \\
\hline 6 & .63 & .32 & & & & & & & & & & & & \\
\hline 7 & .52 & .42 & & & & & & & & & & & & \\
\hline 8 & .31 & - & & & & & & & & & & & & \\
\hline 9 & & & .66 & .72 & & & & & & & & & & \\
\hline 10 & & & .73 & .71 & & & & & & & & & & \\
\hline 11 & & & .73 & .73 & & & & & & & & & & \\
\hline 12 & & & .57 & .63 & & & & & & & & & & \\
\hline 13 & & & .48 & .77 & & & & & & & & & & \\
\hline 14 & & & .73 & .79 & & & & & & & & & & \\
\hline 15 & & & .61 & .64 & & & & & & & & & & \\
\hline 16 & & & .44 & .60 & & & & & & & & & & \\
\hline 17 & & & & & .51 & .60 & & & & & & & & \\
\hline 18 & & & & & .68 & .68 & & & & & & & & \\
\hline 19 & & & & & .44 & .50 & & & & & & & & \\
\hline 20 & & & & & .65 & .67 & & & & & & & & \\
\hline 21 & & & & & .59 & .51 & & & & & & & & \\
\hline 22 & & & & & .68 & .59 & & & & & & & & \\
\hline 23 & & & & & .56 & .56 & & & & & & & & \\
\hline 24 & & & & & .68 & .51 & & & & & & & & \\
\hline 25 & & & & & & & .47 & .66 & & & & & & \\
\hline 26 & & & & & & & .41 & .72 & & & & & & \\
\hline 27 & & & & & & & .50 & .77 & & & & & & \\
\hline 28 & & & & & & & .45 & .68 & & & & & & \\
\hline 29 & & & & & & & .57 & .81 & & & & & & \\
\hline 30 & & & & & & & .60 & .78 & & & & & & \\
\hline 31 & & & & & & & .70 & .78 & & & & & & \\
\hline 32 & & & & & & & .68 & .76 & & & & & & \\
\hline 33 & & & & & & & & & .54 & .69 & & & & \\
\hline 34 & & & & & & & & & .44 & .69 & & & & \\
\hline 35 & & & & & & & & & .47 & .67 & & & & \\
\hline 36 & & & & & & & & & .64 & .71 & & & & \\
\hline 37 & & & & & & & & & .60 & .71 & & & & \\
\hline 38 & & & & & & & & & .60 & .71 & & & & \\
\hline 39 & & & & & & & & & .65 & .70 & & & & \\
\hline 40 & & & & & & & & & .57 & .73 & & & & \\
\hline 41 & & & & & & & & & & & .51 & .65 & & \\
\hline 42 & & & & & & & & & & & .50 & .57 & & \\
\hline
\end{tabular}


Table 15 Factor loadings for the Korean and Thai versions of WIHIC (Continued)

\begin{tabular}{|c|c|c|c|c|c|c|c|c|c|c|c|c|c|c|}
\hline \multirow[t]{2}{*}{ Item No. } & \multicolumn{2}{|c|}{$\begin{array}{l}\text { Student } \\
\text { cohesiveness }\end{array}$} & \multicolumn{2}{|c|}{$\begin{array}{l}\text { Teacher } \\
\text { support }\end{array}$} & \multicolumn{2}{|c|}{ Involvement } & \multicolumn{2}{|c|}{ Investigation } & \multicolumn{2}{|c|}{$\begin{array}{l}\text { Task } \\
\text { orientation }\end{array}$} & \multicolumn{2}{|c|}{ Cooperation } & \multicolumn{2}{|c|}{ Equity } \\
\hline & Thai & Kor & Thai & Kor & Thai & Kor & Thai & Kor & Thai & Kor & Thai & Kor & Thai & Kor \\
\hline 43 & & & & & & & & & & & .63 & .63 & & \\
\hline 44 & & & & & & & & & & & .61 & .67 & & \\
\hline 45 & & & & & & & & & & & .62 & .71 & & \\
\hline 46 & & & & & & & & & & & .69 & .74 & & \\
\hline 47 & & & & & & & & & & & .65 & .74 & & \\
\hline 48 & & & & & & & & & & & .51 & .64 & & \\
\hline 49 & & & & & & & & & & & & & .57 & .70 \\
\hline 50 & & & & & & & & & & & & & .68 & .70 \\
\hline 51 & & & & & & & & & & & & & .72 & .59 \\
\hline 52 & & & & & & & & & & & & & .71 & .76 \\
\hline 53 & & & & & & & & & & & & & .73 & .76 \\
\hline 54 & & & & & & & & & & & & & .75 & .70 \\
\hline 55 & & & & & & & & & & & & & .58 & .70 \\
\hline 56 & & & & & & & & & & & & & .70 & .75 \\
\hline
\end{tabular}

Loadings smaller than 0.3 omitted 


\section{Appendix 2}

Table 16 Factor loadings for the Korean and Thai versions of CLEQ

\begin{tabular}{|c|c|c|c|c|c|c|c|c|c|c|c|c|c|c|}
\hline \multirow{2}{*}{$\begin{array}{l}\text { Item } \\
\text { No. }\end{array}$} & \multicolumn{2}{|c|}{ Equity } & \multicolumn{2}{|c|}{ Collaboration } & \multicolumn{2}{|c|}{ Teacher Authority } & \multicolumn{2}{|c|}{ Competition } & \multicolumn{2}{|c|}{ Deference } & \multicolumn{2}{|c|}{ Modeling } & \multicolumn{2}{|c|}{ Congruence } \\
\hline & Thai & Kor & Thai & Kor & Thai & Kor & Thai & Kor & Thai & Kor & Thai & Kor & Thai & Kor \\
\hline 65 & .76 & .82 & & & & & & & & & & & & \\
\hline 66 & .71 & .76 & & & & & & & & & & & & \\
\hline 67 & .68 & .82 & & & & & & & & & & & & \\
\hline 68 & .42 & .85 & & & & & & & & & & & & \\
\hline 69 & .48 & .66 & & & & & & & & & & & & \\
\hline 70 & & & .80 & .88 & & & & & & & & & & \\
\hline 71 & & & .61 & .85 & & & & & & & & & & \\
\hline 72 & & & - & .86 & & & & & & & & & & \\
\hline 73 & & & .40 & .67 & & & & & & & & & & \\
\hline 74 & & & .67 & .86 & & & & & & & & & & \\
\hline 75 & & & & & .59 & .70 & & & & & & & & \\
\hline 76 & & & & & .68 & .75 & & & & & & & & \\
\hline 77 & & & & & .70 & .76 & & & & & & & & \\
\hline 78 & & & & & .36 & .49 & & & & & & & & \\
\hline 79 & & & & & .31 & .45 & & & & & & & & \\
\hline 80 & & & & & & & .73 & .74 & & & & & & \\
\hline 81 & & & & & & & .79 & .71 & & & & & & \\
\hline 82 & & & & & & & .53 & .57 & & & & & & \\
\hline 83 & & & & & & & .71 & .79 & & & & & & \\
\hline 84 & & & & & & & .61 & .62 & & & & & & \\
\hline 85 & & & & & & & & & .63 & .68 & & & & \\
\hline 86 & & & & & & & & & .71 & .63 & & & & \\
\hline 87 & & & & & & & & & .60 & .67 & & & & \\
\hline 88 & & & & & & & & & .65 & .77 & & & & \\
\hline 89 & & & & & & & & & .69 & .79 & & & & \\
\hline 90 & & & & & & & & & & & .51 & .78 & & \\
\hline 91 & & & & & & & & & & & .50 & .80 & & \\
\hline 92 & & & & & & & & & & & .65 & .71 & & \\
\hline 93 & & & & & & & & & & & .73 & .80 & & \\
\hline 94 & & & & & & & & & & & .64 & .61 & & \\
\hline 95 & & & & & & & & & & & & & .58 & .68 \\
\hline 96 & & & & & & & & & & & & & .70 & .78 \\
\hline 97 & & & & & & & & & & & & & .64 & .77 \\
\hline 98 & & & & & & & & & & & & & .71 & .82 \\
\hline 99 & & & & & & & & & & & & & .66 & .83 \\
\hline
\end{tabular}

Loadings smaller than 0.3 omitted

\section{Abbreviations}

CLEQ: Cultural Learning Environment Questionnaire; WIHIC: What Is Happening In this Class

\section{Acknowledgements}

This work was supported by the Ministry of Education of the Republic of Korea and the National Research Foundation of Korea (NRF-2016S1A3A2925401). 


\section{Funding}

This work was supported by the Ministry of Education of the Republic of Korea and the National Research Foundation of Korea (NRF-2016S1A3A2925401).

\section{Availability of data and materials}

The data is not available for sharing due to the confidentiality clause included in the informed consent for the study.

\section{Authors' contributions}

All authors contributed equally to this work. All authors commented on the manuscript at all stages. All authors read and approved the final manuscript.

\section{Authors' information}

Jina Chang is a researcher at the Center for Educational Research from Seoul National University, Seoul, South Korea. Her research interests are in the areas of inquiry in school science, primary science education, and sociocultural contexts. She has expanded her research interests into the impacts of technologies in school science inquiry from sociocultural perspectives.

Chatree Faikhamta is an Associate Professor at Faculty of Education, Kasetsart University, Thailand. His research areas focus on pedagogical content knowledge (PCK), self-study research and action research. He directed the nationally funded Developing PCK-based professional development program for prospective science teachers and their school supervisors. Jiyeon Na is an Associate Professor at Chuncheon National University of Education, Chuncheon, South Korea. Her research interests are in the areas of primary science education, Technological Pedagogical and Content Knowledge (TPACK) and teacher education. Especially, her research focuses on the forming process of TPACK in pre-service teachers' training. Jinwoong Song is a Professor of Physics Education at Seoul National University in Seoul, South Korea. His main areas of research include physics teaching and learning, philosophy and history of science education and science classroom culture. He is particularly interested in understanding the features of science culture in East Asia and developing the culturally appropriate pedagogies in science classrooms in East Asia.

\section{Ethics approval and consent to participate}

The data collected from this project has obtained the necessary clearance from the school and the students involved in the study.

\section{Consent for publication}

The authors agree that this article will be published in the APSE journal.

\section{Competing interests}

The authors declare that they have no competing interests.

\section{Publisher's Note}

Springer Nature remains neutral with regard to jurisdictional claims in published maps and institutional affiliations.

\section{Author details}

${ }^{1}$ Department of Science Education, College of Education, Seoul National University, Seoul, Republic of Korea. ${ }^{2}$ Faculty of Education, Kasetsart University, Ladyao, Chatuchak, Bangkok, Thailand. ${ }^{3}$ Chuncheon National University of Education, Chuncheon, South Korea. ${ }^{4}$ Center for Educational Research, Seoul National University, Seoul, Republic of Korea.

Received: 29 April 2018 Accepted: 21 June 2018

Published online: 25 July 2018

\section{References}

Aldridge, J. M., \& Fraser, B. (2000). A cross-cultural study of classroom learning environments in Australia and Taiwan. Learning Environments Research, 3(2), 101-134.

Aldridge, J. M., Fraser, B. J., \& Huang, T. I. (1999). Investigating classroom environments in Taiwan and Australia with multiple research methods. Journal of Educational Research, 93(1), 48-62.

Aldridge, J. M., Fraser, B. J., Taylor, P., \& Chen, C. C. (2000). Constructivist learning environments in a cross national study in Taiwan and Australia. International Journal of Science Education, 22(1), 37-55.

Chang, J., Na, J., \& Song, J. (2015). Reinterpretation of learning environment instruments from cultural perspectives: Exploring the applicability for understanding science classroom cultures. Journal of Korean Elementary Science Education, 34(2), 238-251.

Cheevapitakpol, A. (2014). Comparative study of social culture between Korea and Thailand: Through approach of G. Hofstede theory (Master's thesis). Retrieved from http://dcollection.ewha.ac.kr/public_resource/pdf/000000084642 20180703214512.pdf.

Choi, K. (2003). Strategy for activating science education for woman: Analyzing girl-friendly science education program and teaching/learning materials of other countries. Journal of Science and Technology Studies, 3(1), 19-39.

Chung, J. S. (1994). Women's unequal access to education in South Korea. Comparative Education Review, 38(4), 487-505.

Croll, E. (2000). Endangered daughters: Discrimination and development in Asia. London: Psychology Press.

Dorman, J. P. (2003). Cross-national validation of the what is happening in this class? (WIHIC) questionnaire using confirmatory factor analysis. Learning Environments Research, 6(3), 231-245.

Dorman, J. P., Aldridge, J. M., \& Fraser, B. J. (2006). Using students' assessment of classroom environment to develop a typology of secondary school classrooms. International Education Journal, 7(7), 906-915. 
Faikhamta, C., \& Ladachart, L. (2016). Science education in Thailand: Moving through crisis to opportunity. In M. H. Chiu (Ed.), Science education research and practice in Asia (pp. 197-214). Singapore: Springer.

Fisher, D. L., \& Waldrip, B. G. (1997). Assessing culturally sensitive factors in the learning environment of science classrooms. Research in Science Education, 27(1), 41-49.

Fisher, D. L., \& Waldrip, B. G. (1999). Cultural factors of science classroom learning environments, teacher-student interactions and student outcomes. Research in Science \& Technological Education, 17(1), 83-96.

Fiske, A. P., Kitayama, S., Markus, H. R., \& Nisbett, R. E. (1998). The cultural matrix of social psychology. In D. T. Gilbert, S. T. Fiske, \& G. Lindzey (Eds.), The Handbook of social psychology (pp. 915-981). lowa: The McGraw-Hill Co.

Fraser, B. J. (1998). Classroom environment instruments: Development, validity and applications. Learning environments research, 1(1), 7-34.

Fraser, B. J. (2002). Learning environments research: Yesterday, today and tomorrow. In G. S. Chiew \& K. M. Swe (Eds.), Studies in educational learning environments: An international perspective (pp. 1-25). London: World Scientific.

Fraser, B. J., McRobbie, C., \& Fisher, D. L. (1996). Development, validation and use of personal and class forms of a new classroom environment questionnaire. Proceedings Western Australian Institute for Educational Research Forum 1996. Retrieved from http://www.waier.org.au/forums/1996/fraser.html.

Geertz, C. (1973). The growth of culture and the evolutions of mind. In C. Geertz (Ed.), The interpretation of cultures (pp. 55-87). New York: Basic Books.

Hofstede, G. (1983). The cultural relativity of organizational practices and theories. Journal of International Business Studies, 14(2), 75-89.

Hofstede, G. (1986). Cultural differences in teaching and learning. International Journal of intercultural relations, 10(3), 301-320.

Hofstede, G. (1991). Cultures and organizations: Software of the mind. London: McGraw-Hill.

Hong, M., Kang, N.-H., \& Kim, J.-A. (2010). Middle school students' perceptions of science classroom learning environments. Journal of the Korean Association for Science Education, 30(1), 68-79.

Jhun, Y. S., \& Shin, Y.-J. (2004). Evaluation on the implementation of girl friendly science activity. Journal of the Korean Association for Science Education, 24(3), 442-458.

Joo, Y., Kim, K., \& Noh, T. (2012). The effects of grouping by middle school students' collectivism in science cooperative learning and their perceptions. Journal of the Korean Association for Science Education, 32(2), 1551-1566.

Jung, H.-S. (2013). A study on the language cultures and their backgrounds of Korea and Thailand. Journal of the Korean Association of Thai Studies, 20(1), 79-121.

Khine, M. S., \& Fisher, D. L. (2004). Teacher interaction in psychosocial learning environments: Cultural differences and their implications in science instruction. Research in Science \& Technological Education, 22(1), 99-111.

Kim, H. B., Fisher, D. L., \& Fraser, B. J. (1999). Assessment and investigation of constructivist science learning environments in Korea. Research in Science \& Technological Education, 17(2), 239-249.

Kim, H. B., Fisher, D. L., \& Fraser, B. J. (2000). Classroom environment and teacher interpersonal behaviour in secondary science classes in Korea. Evaluation \& Research in Education, 14(1), 3-22.

Kim, K.-D. (2011). How are we to understand Asia?: Perceptions and identities. Asia Review, 1(1), 37-58.

Lave, J., \& Wenger, E. (1991). Legitimate peripheral participation. In Situated learning. Cambridge: Cambridge university press.

OECD. (2016). PISA results (Volume I): Excellence and equity in education. Paris: OECD Publishing

Palmer, D. (2007). What is the best way to motivate students in science? Teaching Science, 53(1), 38-42.

Sewell Jr., W. H. (1999). The concept(s) of culture. In V. E. Bonnell \& L. Hunt (Eds.), Beyond the cultural turn: New directions in the study of society and culture (pp. 35-61). Berkeley: University of California Press.

Singh, M., \& McNeil, J. T. (2014). Do learning environments differ across subjects and nations: Case studies in Hawaii and Singapore using the WIHIC questionnaire. Learning Environments Research, 17(2), 173-189.

Song, J. (2013). The disparity between achievement and engagement in students' science learning: A case of east-Asian regions. In C. Deborah, R. Gunstone, \& A. Jones (Eds.), Valuing assessment in science education: Pedagogy, curriculum, policy (pp. 285-306). Dordrecht: Springer.

Sorensen, C. W. (1994). Success and education in South Korea. Comparative Education Review, 38(1), 10-35.

Sumida, M., Saruta, Y., Inada, Y., \& Lin, S.-F. (2016). Diversity dilemmas of Science Education in East Asia. In H. Lin, J. K. Gilbert, \& C.-J. Lien (Eds.), Science education research and practice in East Asia: Trends and Perspectives (pp. 191-216). East-Asian Association for Science Education). Taiwan: Higher Education Publishing.

Vygotsky, L. S. (1978). Mind in society: The development of higher mental process. Cambridge: Harvard University Press.

\section{Submit your manuscript to a SpringerOpen ${ }^{\circ}$ journal and benefit from:}

- Convenient online submission

- Rigorous peer review

- Open access: articles freely available online

- High visibility within the field

- Retaining the copyright to your article

Submit your next manuscript at $\mathbf{s p r i n g e r o p e n . c o m ~}$ 